University of Nebraska - Lincoln

DigitalCommons@University of Nebraska - Lincoln

Publications, Agencies and Staff of the U.S.

Department of Commerce

U.S. Department of Commerce

2007

\title{
Characterization of eight microsatellite loci in Steller sea lions (Eumetopias jubatus)
}

Ryan M. Huebinger

Texas A\&M University, College Station

Edward E. Louis Jr.

Center for Conservation and Research, Henry Doorly Zoo

Thomas Gelatt

National Marine Mammal Laboratory, Alaska Fisheries Science Center, National Marine Fisheries Service

Lorrie D. Rea

Marine Mammals Section, Division of Wildlife Conservation, Alaska Department of Fish and Game, University of Alaska Fairbanks

John W. Bickham

Texas A\&M University, College Station

Follow this and additional works at: https://digitalcommons.unl.edu/usdeptcommercepub

Part of the Environmental Sciences Commons

Huebinger, Ryan M.; Louis Jr., Edward E.; Gelatt, Thomas; Rea, Lorrie D.; and Bickham, John W., "Characterization of eight microsatellite loci in Steller sea lions (Eumetopias jubatus)" (2007). Publications, Agencies and Staff of the U.S. Department of Commerce. 201.

https://digitalcommons.unl.edu/usdeptcommercepub/201

This Article is brought to you for free and open access by the U.S. Department of Commerce at DigitalCommons@University of Nebraska - Lincoln. It has been accepted for inclusion in Publications, Agencies and Staff of the U.S. Department of Commerce by an authorized administrator of DigitalCommons@University of Nebraska - Lincoln. 


\title{
PRIMER NOTE Characterization of eight microsatellite loci in Steller sea lions (Eumetopias jubatus)
}

\author{
RYAN M. HUEBINGER,*IIEDWARD E. LOUIS JR,†THOMAS GELATT, $\nmid$ LORRIE D. REA§ \\ and JOHN W. BICKHAM*II \\ *Department of Wildlife and Fisheries, Texas AEM University, College Station, TX 77843, USA, +Center for Conservation and \\ Research, Henry Doorly Zoo, 3701 South 10th Street, Omaha, NE 68107, USA, †National Marine Mammal Laboratory, Alaska \\ Fisheries Science Center, National Marine Fisheries Service, 7600 Sand Point Way, NE, Seattle, WA 98115-6349, USA, §Marine \\ Mammals Section, Division of Wildlife Conservation, Alaska Department of Fish and Game, University of Alaska Fairbanks, 245 \\ O'Neill Building, Fairbanks, AK 99775-7220, USA, IICurrent address: Centre for the Environment, Department of Forestry and \\ Natural Resources, Purdue University, West Lafayette, IN 47907, USA
}

\begin{abstract}
Steller sea lions (Eumetopias jubatus) are listed as an endangered species in western Alaska and have exhibited a significant population decline throughout their range. Eight microsatellite loci were isolated from genomic DNA libraries. In addition, all these markers were found to be variable in nine individuals of the California sea lion (Zalophus californicus). This panel of markers was developed to analyse population structure in Steller sea lions throughout their range.
\end{abstract}

Keywords: Eumetopias, microsatellites, Steller sea lion

Received 6 August 2006; revision accepted 12 March 2007

The Steller sea lion (Eumetopias jubatus) is distributed throughout the North Pacific Ocean and Bering Sea. Rookeries occur along the North Pacific Rim from the Sea of Okhotsk and Kuril Islands; north to the Commander Islands; east through the Aleutian Island chain to mainland Alaska; and south to California (Loughlin et al. 1987). This species has experienced a marked decline from an estimated 240 000-300 000 individuals in the 1960s (Kenyon \& Rice 1961) to an estimated 116000 individuals in 1989 (Loughlin et al. 1992). Population numbers in the USA have declined by about $75 \%$ over the past 20 years (Calkins et al. 1999) with most of the decline occurring in the western portion of their range. Several studies have investigated the decline of Steller sea lions, but the exact cause remains elusive (Loughlin 1998). Suggested causes include reduced prey availability, historical sea lion pup harvest, diseases, predation, and environmental changes. Genetic studies of Steller sea lions have been conducted to investigate the phylogeographic structure of the populations, to identify management units, and to document the potential loss

Correspondence: John W. Bickham, Centre for the Environment, Purdue University, West Lafayette, IN 47907-2966, USA. Fax: (765)496-1369; E-mail: bickham@purdue.edu of genetic diversity resulting from the decline using mtDNA markers (Bickham et al. 1998; Baker et al. 2005). In addition, studies utilizing microsatellite data, mainly derived from loci described from distantly related pinnipeds, across the range of Steller sea lions have been conducted (Hoffman et al. 2006).

Genomic DNA was isolated from Steller sea lion and northern fur seal (Callorhinus ursinus) flipper punches using a standard protocol (Sambrook et al. 1989). A procedure for creation of a genomic library enriched for microsatellites was carried out as described in An et al. (2004). A brief overview of the enrichment protocol follows. Genomic DNA was digested with Sau3AI and then size selected utilizing Chroma Spin columns (Clontech Laboratories, Chroma Spin + TE-400). Fragments were then ligated to linker molecules described in An et al. (2004). Enrichment for CA repeats was accomplished utilizing biotinylated oligoprobe and Vectrex Avidin D (Vector Laboratories). Enriched fragments were then ligated into pCR 2.1 TOPO vector (Invitrogen). Ligated DNA was transformed into Escherichia coli. Colonies that contained inserts were hybridized to a $(\mathrm{CA})_{10}$ oligoprobe. Screening of 1000 clones yielded 19 positives. Primers for polymerase chain reaction (PCR) amplification were designed from the 
Table 1 Primer sequences, allele characteristics, sizes, and number $(k)$ of eight Eumetopias jubatus microsatellites, observed and expected heterozygosities with Hardy-Weinberg probabilities, as screened across 20 Steller sea ions

\begin{tabular}{|c|c|c|c|c|c|c|c|c|c|}
\hline Locus & Primer sequence ( $5^{\prime}$ to $\left.3^{\prime}\right)$ & Repeat motif & $\begin{array}{l}\text { Annealing } \\
\text { temp. }\left({ }^{\circ} \mathrm{C}\right)\end{array}$ & $\begin{array}{l}\text { GenBank } \\
\text { accession No. }\end{array}$ & $\begin{array}{l}\text { Fragment } \\
\text { size (bp) }\end{array}$ & $\mathrm{k}$ & $H_{\mathrm{O}}$ & $H_{\mathrm{E}}$ & $\begin{array}{l}\text { Prob } \\
\text { HWE }\end{array}$ \\
\hline 13HDZ462 & $\begin{array}{l}\text { F-AGG CTT AAA ATC ACA AAA CAT CAG } \\
\text { R-TTA CCA GAC AGT GTT ATT GAC GC }\end{array}$ & $(\mathrm{CA})_{19}$ & 54 & DQ777851 & $125-131$ & 3 & 0.35 & 0.432 & $0.0345^{*}$ \\
\hline 71HDZ2x & $\begin{array}{l}\text { F-GTC ACA CCA TAT GTT TTG TGT AAT TAC } \\
\text { R-HEX ATA TTT ATA AAA TGT TAG ACT AAT GTA GCT TC }\end{array}$ & $(\mathrm{CA})_{4} \mathrm{AA}(\mathrm{CA})_{13}$ & 52 & DQ777840 & 139-141 & 2 & 0.526 & 0.512 & 1.0 \\
\hline 71HDZ301 & $\begin{array}{l}\text { F-GTG AAA GAA ACC TGA TGC TGC } \\
\text { R-HEX AAG TCA TAG CCA GTC TCC TTA CAG }\end{array}$ & $(\mathrm{CA})_{14}$ & 53 & DQ777847 & $255-259$ & 3 & 0.5 & 0.575 & 0.6208 \\
\hline 71HDZ 441 & $\begin{array}{l}\text { F-HEX ACC TTT TCA TTT GCC TCC TC } \\
\text { R-GCC TCA GAG AGA CCA GTG TGC }\end{array}$ & $(\mathrm{CA})_{13}$ & 58 & DQ777849 & $304-306$ & 2 & 0.158 & 0.149 & 1.0 \\
\hline 71HDZ 529 & $\begin{array}{l}\text { F-6-FAM GAT CCA TTA CTA GAC AGA CAG ACA GAC } \\
\text { R-GTT TTG CTT CTT CAC ACC ATA TAC }\end{array}$ & $(\mathrm{CA})_{15}$ & 50 & DQ777850 & $201-211$ & 5 & 0.684 & 0.648 & 0.3951 \\
\hline 71HDZ 5A & $\begin{array}{l}\text { F-6-FAM GTG GGG CAT AAC ACA ATC TG } \\
\text { R-TCT TCC TAC CTC TGC TCT CTC C }\end{array}$ & $(\mathrm{GT})_{25}$ & 54 & DQ777853 & $160-168$ & 4 & 0.235 & 0.401 & $0.0449^{*}$ \\
\hline 71HDZ 5x & $\begin{array}{l}\text { F-6-FAM CTT TAG ACC ATT GCT TTT AGA CTT C } \\
\text { R-GTT GCC ATG ACA TTT AGC TTT G }\end{array}$ & $(\mathrm{CA})_{18}$ & 50 & DQ777841 & $304-310$ & 3 & 0.474 & 0.421 & 0.5198 \\
\hline 71HDZ 15 & $\begin{array}{l}\text { F-HEX AGA AAG GTA ACT GGG GAG AGG } \\
\text { R-ACA AAG TGG GAA AGT GAG TGC }\end{array}$ & $(\mathrm{GT})_{15}$ & 54 & DQ777852 & $178-186$ & 5 & 0.7 & 0.587 & 0.5243 \\
\hline
\end{tabular}

*denotes significant deviation from Hardy-Weinberg equilibrium $P<0.05$. 
Table 2 Cross-species amplification results using the primers developed for Steller sea lion. The number of alleles for each locus from 12 California sea lions (Zalophus californicus) are shown in the first row. Allele size range for each locus is Z. californicus are listed in the second row. $71 \mathrm{HDZ} 15$ was not tested with regards to cross amplification

\begin{tabular}{lccccccc}
\hline Species & 13HDZ462 & 71HDZ2x & 71HDZ301 & 71HDZ 441 & 71HDZ 529 & 71HDZ 5A & 71HDZ 5x \\
\hline Z. californicus & 5 & 4 & 4 & 2 & 7 & 9 & 3 \\
& $125-149$ & $139-147$ & $259-267$ & $300-302$ & $203-217$ & $143-176$ & $300-304$ \\
\hline
\end{tabular}

flanking regions, which were selected for analysis based on a high repeat number using MACVECTOR 6.5.3 (Oxford Molecular Group). Loci were determined to be polymorphic based on PCR fragment size when screened across 20 Eumetopias and nine California sea lions (Zalophus californicus). Loci were screened for polymorphism by electrophoresing on 3\% agarose gels. One of the eight loci (13HDZ462) was developed from the sequence of a clone containing a northern fur seal insert and the remaining seven were obtained from Steller sea lion inserts.

Genomic DNA was isolated from tissue samples and PCR amplification was performed in a $25-\mu \mathrm{L}$ reaction volume using an ABI 2700 thermocycler (PerkinElmer) with approximately $50 \mathrm{ng}$ of genomic DNA as template. Final amplification conditions consisted of 12.5 pmol unlabelled reverse primer, 12.5 pmol fluorescently labelled forward primer, $1.5 \mathrm{mM} \mathrm{MgCl}_{2}, 200 \mu \mathrm{M}$ of each dNTP, and $0.5 \mathrm{U}$ of Taq DNA polymerase (Promega). The PCR amplification profile was $95{ }^{\circ} \mathrm{C}$ for $5 \mathrm{~min}$, followed by 35 cycles at $95{ }^{\circ} \mathrm{C}$ for $30 \mathrm{~s}$, a primer-specific annealing temperature for $30 \mathrm{~s}$ (Table 1 ), $72{ }^{\circ} \mathrm{C}$ for $30 \mathrm{~s}$, and ending with a single extension at $72{ }^{\circ} \mathrm{C}$ for $10 \mathrm{~min}$.

Allele sizes were determined by fragment separation on a 7\% polyacrylamide gel electrophoresed on an ABI 377 DNA Analyser (Applied Biosystems, Inc.). Fragment lengths were assigned by the GENESCAN software program (Applied Biosystems, Inc.) using GeneScan-400 [ROX] size standard. Heterozygosity values for each locus were calculated, and tests for Hardy-Weinberg equilibrium of the genotypic frequencies were carried out using GENEPOP version 3.1 software package (Raymond \& Rousset 1995). Additionally, loci were tested for linkage disequilibrium in GENEPOP version 3.1 and no significant linkages were detected among these loci. Primer sequences, annealing temperature, repeat motif, GenBank accession number for each locus, number and size of alleles, and the heterozygosity values for each of the markers are presented in Table 1. Two loci, 13HDZ462 and 71HDZ5A, differed significantly from Hardy-Weinberg equilibrium $(P<0.05)$. The excess of homozygotes detected as deviations from Hardy-Weinberg equilibrium could be created as an effect of sampling error and sample size. The number of alleles found ranged from two to five alleles per locus within Steller sea lions. In addition, the nine Californian sea lions had an equal or greater number of alleles at each locus when compared to the Steller sea lions, with the range of alleles per locus being two to nine alleles (Table 2).

The suite of markers will be utilized to analyse a more extensive collection of Steller sea lion samples throughout their range.

\section{Acknowledgements}

The National Marine Fisheries Service, the Alaska Department of Fish and Game, and the Henry Doorly Zoo provided funding for this study. Specimens were humanely treated and collected under Marine Mammal Protection Act permits 782-1532-02 and 358-1546.

\section{References}

An J, Sommer JA, Shore GD, Williamson JE, Brenneman RA, Louis EE Jr (2004) Characterization of 20 microsatellite marker loci in the West Indian rock iguana (Cyclura nubila). Conservation Genetics, 5 (1), 121-125.

Baker AR, Loughlin TR, Burkanov V et al. (2005) Variation of mitochondrial control region sequences of Steller sea lions, Eumetopias jubatus: The three-stock hypothesis. Journal of Mammalogy, 86, 1075-1084.

Bickham JW, Loughlin TR, Wickliffe JK, Burkanov VN (1998) Geographic variation in the mitochondrial DNA of Steller sea lions: haplotype diversity and endemism in the Kuril Islands. Biosphere Conservation, 11, 107-117.

Calkins DG, McAllister DC, Pitcher KW, Pendleton GW (1999) Steller sea lion status and trend in southeast Alaska: 1979-97. Marine Mammal Science, 15, 462-477.

Hoffman JI, Matson CW, Amos W, Loughlin TR, Bickham JW (2006) Deep genetic subdivision within a continuously distributed and highly vagile marine mammal, the Steller's sea lions Eumetopias jubatus. Molecular Ecology, 15, 2821-2832.

Kenyon KW, Rice DW (1961) Abundance and distribution of the Steller sea lion. Journal of Mammalogy, 42, 223-234.

Loughlin TR (1998) The Steller sea lion: a declining species. Biosphere Conservation, 1, 91-98.

Loughlin TR, Perez MA, Merrick RL (1987) Eumetopias jubatus. Mammalian Species, 283, 1-7.

Loughlin TR, Perlov AS, Vladimirov VA (1992) Range-wide survey and estimation of total number of Steller sea lions in 1989. Marine Mammal Science, 8, 220-239.

Raymond M, Rousset F (1995) GENEPOP version 1.2: population genetics software for exact tests and ecumenicism. Journal of Heredity, 86, 248-249.

Sambrook J, Fritch EF, Maniatus T (1989) Molecular Cloning: A Laboratory Manual, 2nd edn. Cold Spring Harbor Press, New York. 